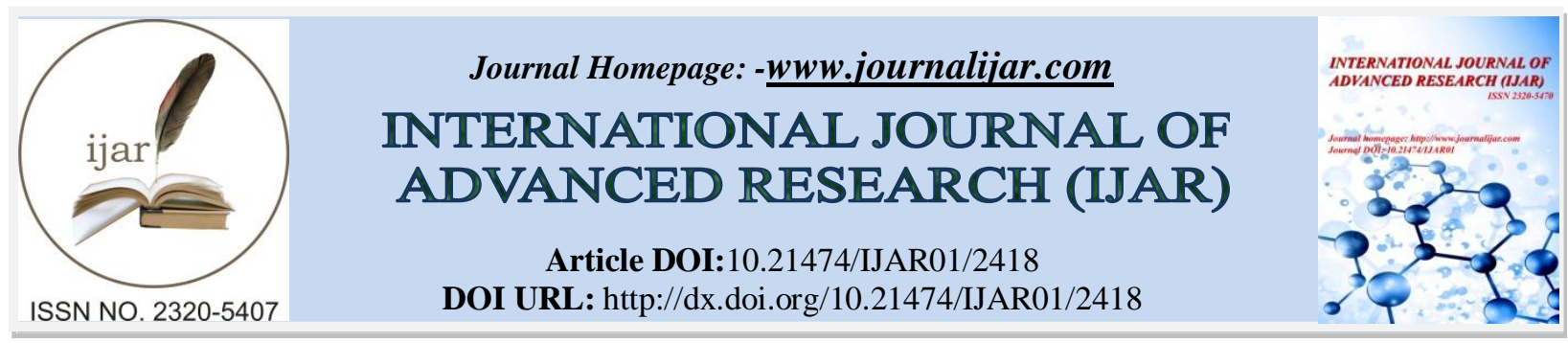

RESEARCH ARTICLE

\title{
DESIGN OF EXPELLING MACHINE FOR BRIQUETTES MADE OF OBTAINED BIO-CHARS FROM CASHEW NUT SHELLS' PYROLYSIS
}

Thierry Godjo ${ }^{1,2}$, Léandre Vissoh ${ }^{1}$, Clotilde Guidi ${ }^{1}$, Alain Adomou ${ }^{1}$ and Sanya Emile ${ }^{2}$.

1. Department of Mechanical Engineering, University Institute of Technology of Lokossa, B.P. 133 LOKOSSA, Benin.

2. Laboratory for Applied Energy and Mechanics (LEMA), EPAC, Abomey-Calavi, Benin.

\section{Manuscript Info}

(.........................

Manuscript History

Received: 20 October 2016

Final Accepted: 22 November 2016

Published: December 2016

Key words:-

Cashew Nut Shell,Briquettes,

Expelling,Machine Design,

Benin

\section{Abstract}

In the context of densification of biochar made from cashew nut shells' pyrolysis, the University Institute of Technology of Lokossa has successively developed two small scale equipments: a manual lever press and a hydraulic press. Although both the developed equipments had significant densification rates $(81 \%$ and $85 \%$ respectively for manual lever press and hydraulic press), it remains to enhance the throughput $(10 \mathrm{~kg} / \mathrm{hr}$ and $90 \mathrm{~kg} / \mathrm{hr}$ respectively for manual lever press and hydraulic press).This paper presents the design of an efficient Expelling Machine for Briquettes made from cashew nut shells pyrolysis biochars. The machine has been designed to a capacity of $500 \mathrm{~kg} / \mathrm{hr}$ and can expel briquettes at the rate of 1,000 briquettes $/ \mathrm{hr}$. The machine is powered using electric motor of $7 \mathrm{~kW}$ to be operated for 8 working hours. This machine improves the performances of existing briquetting technologies and it will enhance the environmental footprint.

Copy Right, IJAR, 2016,. All rights reserved.

\section{Introduction:-}

World energy consumption is dominated by fossil energy that unfortunately causes gradual depletion of world petroleum reserves and the increasing exhaust emissions on environment and global warming(Höök and Tang, 2013). Due to this there is a need for suitable alternative fuels for use in diesel engines. Indeed, previous researches (Chou, Lin, and Lu 2009; Hassan, Kee, and Al-Kayiem 2013; Rattanongphisat and Chindaruksa 2011)have shown that fuel obtained from the biomass is a safe alternative as fuel.Cashew Nut Shell is one of important sources of energy(Das and Ganesh 2003; Das, Sreelatha, and Ganesh 2004; Tippayawong et al. 2011).

In Benin,the cashew world is known for quality of itsraw product. Benin's cashew nut is very well priced on the international marketfor its quality. In agriculture sector, cashew constitutes Benin's second largest source of revenue after cotton. It is produced in the central and northern regions of country. Collines, Zou, Borgu, Donga, Atacora are the major cashew producing areas in Benin.Since 2001, the area and production of cashew nut in Benin has increased at an annual growth rate of 3.39 and 6.58 per cent respectively(Mensah et al. 2012). The cashew value chain represents an enormous economic, social and environmental opportunityfor Benin. The cashewindustry is a rapidly growing sector in Benin. The cashew processing sector comprises many industrial processing units with a capacity of 1,000 to 100,000 tons/year, whose output is exported to the European market (Afonkantan Benin Cashew factory of Parakou, Kake-5 of Savalou, Nad\& Co of Tchaourou, Tolaro Global Benin of Tourou, La lumiere of

Corresponding Author: -Thierry Godjo.

Address: -Department of Mechanical Engineering, University Institute of Technology of Lokossa, B.P.

133 LOKOSSA, Benin. 
Tchetti, etc.), and small units with a lower capacity of 150 tons/year, whose output is sold on local and regional markets (GK5, AFETRACA, ZANCLAN, SONGHAI Centre, GNICOBOU units, etc.).

Faced to difficulties to energy access and managementof waste from the processing of cashew nutsin Benin, the shells stored in cashew nuts processingplants are directly used as fuel. They are thereforeburned in kilns to provide the energy required to produceheat for embrittlement of nuts, steaming anddrying almonds. This non controlled combustion generates significant pollution because Cashew Nut Shell Liquid (CNSL), substancecontained in cashew nutshells, produces abundant and acridsmoke irritating to eyes(Tagutchou and Naquin, 2012).To overcome the problem of access to energy in Benin, some researches have been carried out on the energy production from cashew shells(Godjo et al., 2015). Thus, two pyrolysis plants have been constructed in Benin, on basis of a reactor designed by CEFREPADE and RONGEAD. Those reactors have been used in Benin for energy recovery from cashew nut shells. Although the pyrolysis products reduce the waste deposit and provide the energy needed for combustion, the exploitation ofbiochars remains incomplete: they are bulky and difficult to transport, because of their low density(Godjo, 2016). In order to help operators tobetter manage and facilitate the transport of biocharbons, the University Institute of Technology of Lokossa has successively developed two small scale equipments: a manual lever press and a hydraulic press. The analysis of physical and mechanical properties of the manuallever pressshowedthat degree of densification, impact resistance of briquettes and resistance to water penetration, were respectively $81 \%, 90 \%$ and 0.94 (Godjo, 2017). Although both the developed equipments had significant densification rates ( $81 \%$ and $85 \%$, respectively for manual lever press and hydraulic press), it remains to enhance the throughput $(10 \mathrm{~kg} / \mathrm{hr}$ and $90 \mathrm{~kg} / \mathrm{hr}$, respectively for manual lever press and hydraulic press). This paper presents the design of an efficient Expelling Machine for Briquettes made of biocharsfrom pyrolysis of cashew nut shells.

\section{Materials and Methods:-}

The Expelling Machine, for Briquettes made of biochars from pyrolysis of cashew nut shells, is designed to have the following components: hopper, screw conveyor, cylinder, power transmission, electric motor, elements (bearings, belts and pulleys). Materials selection for the various components of the machine was based on calculations.

The fully assembled machine is shown in Figure 1

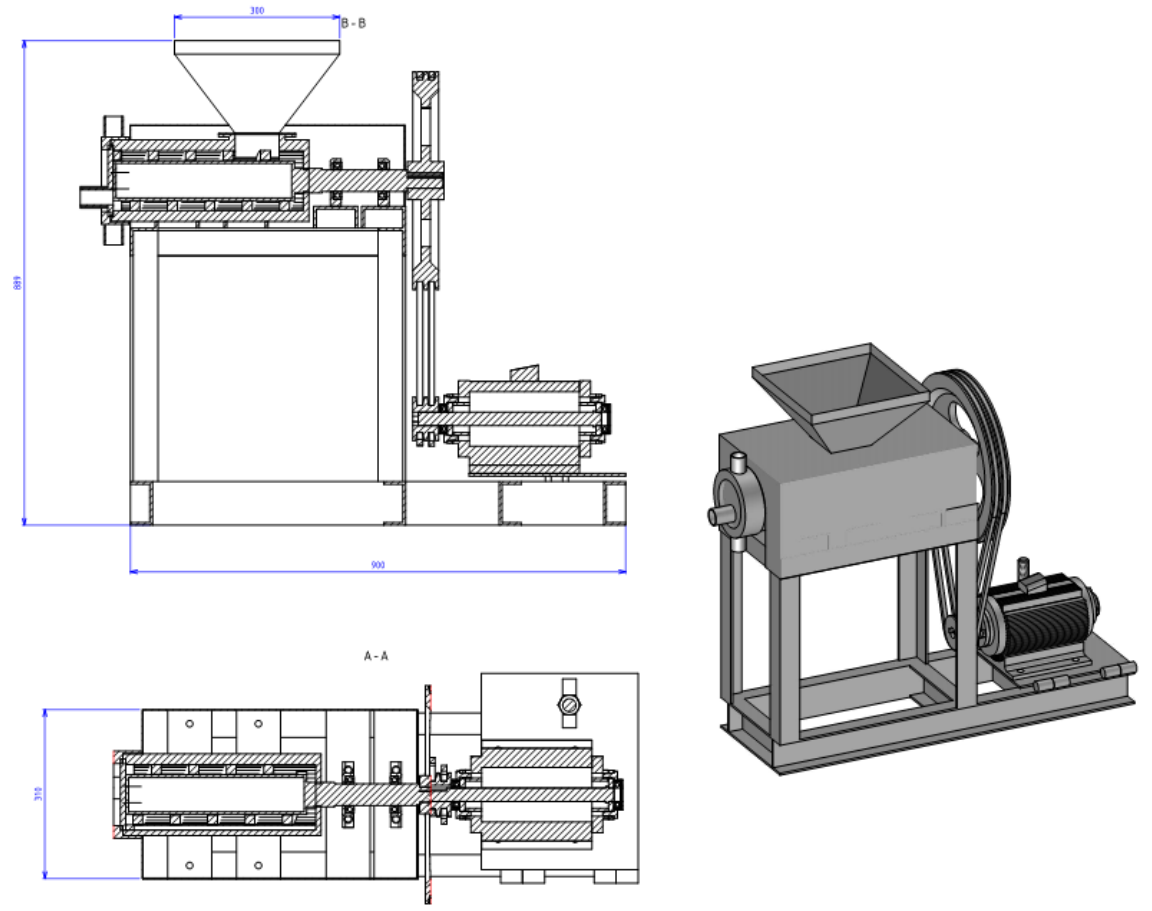

Figure 1:- Assembly drawing of theExpelling Machine for Briquettes made of biochars from pyrolysis of cashew nut shells. 


\section{Design considerations:-}

Electric Motor Selection:-

The electric motor, for the designed machine is selected based on the load characteristics of machine. It is a threephase $50 \mathrm{~Hz}$ motor, for industrial purpose. The power of electric motor is the selected power allowing biomass conveying and rotating of screw shaft. An electric motor, with a power rating of $7 \mathrm{~kW}$, was selected and the speed at shaft-end, $1450 \mathrm{tr} / \mathrm{min}$.

\section{Design power:-}

Design Power $\left(\mathrm{P}_{\mathrm{D}}\right)$ is obtained by multiplying power tobe transmitted by service factor. For screw conveyors, it's known that the service factor is from 0.96 to 0.99 (Wood and Wollenberg 1996).A service factor of 0.96is selected.

$\mathrm{P}_{\mathrm{D}}=P e * \mu$

$\mathrm{P}_{\mathrm{D}}=7 * 0.69=6.72 \mathrm{~kW}$

The torque developed can be obtained using equation(Lemm et al. 2011).

$T=\frac{60}{2 \pi N} * \mathrm{P}_{\mathrm{D}}$

Where $\quad \mathrm{N}$ is the Speed of the shaft

$T=\frac{60}{2 \pi * 1450} * 6.72=42.27(\mathrm{~N} \cdot \mathrm{m} / \mathrm{rad})$

\section{Design of Screw Shaft:-}

The helical flight on the shaft is made from $2.5 \mathrm{~mm}$ thick steel. The helical flight ensures adequate transportation of cashew biomass without bending and at the same time exerts pressure on cashew biomass.

The length of screw is $329 \mathrm{~mm}$ with outside diameter of $111 \mathrm{~mm}$ andconstant throughout the length. The total length of shaft is $599 \mathrm{~mm}$.

The dimensions ofscrew-shaft are shown in Figure 1.

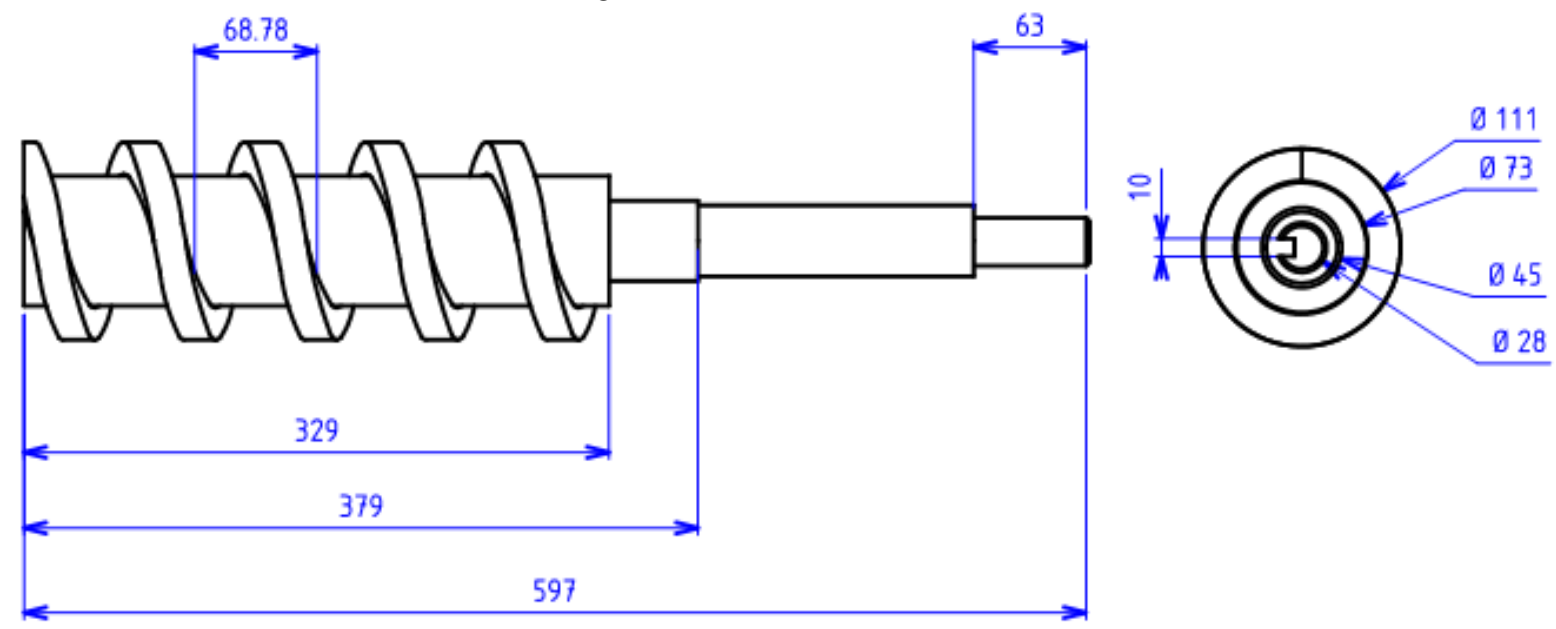

Figure 2:- Screw Shaft Definition Drawing

\section{Design of Cylinder:-}

The screw conveyor press is surrounded by a barrel which is cylindrical. The clearance between the barrel and screw conveyor is taken to be $2.5 \mathrm{~mm}$. Galvanized steel (GS) pipe was used. The length, internal diameter and thickness were $400 \mathrm{~mm}, 150 \mathrm{~mm}$ and $5 \mathrm{~mm}$, respectively. The opening for mounting of hopper was machined from $39 \mathrm{~mm}$ distance at the beginning of barrel. The Cylinder Definition Drawing is presented in Figure 2. 

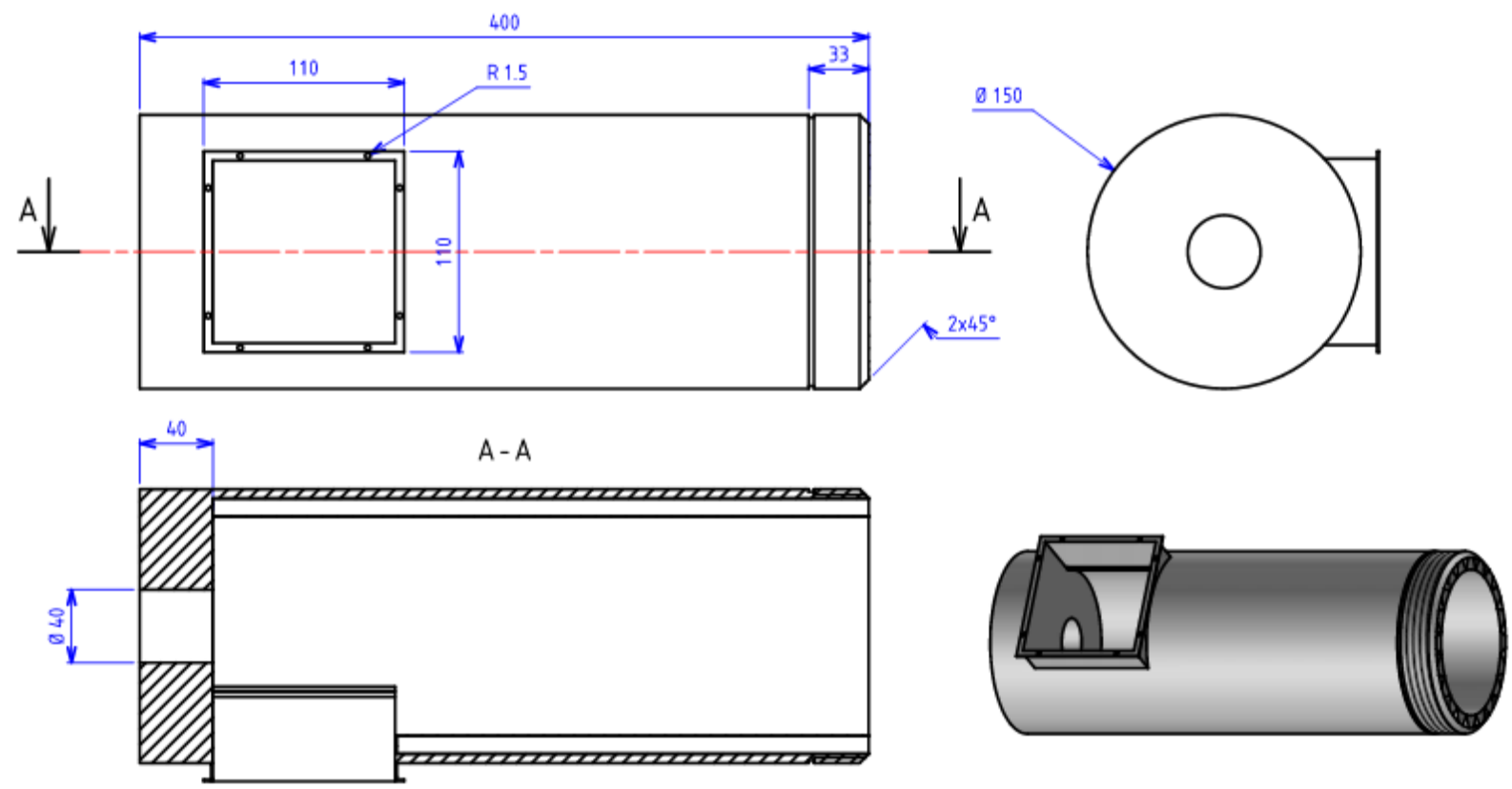

Figure 3:- Cylinder Definition Drawing.

Design of Hopper:-

A square frustum-shaped hopper (as in Figure 4) was constructed and mounted at the cylinder intake. It was constructed from $2 \mathrm{~mm}$ thick mild steel (MS) sheet.
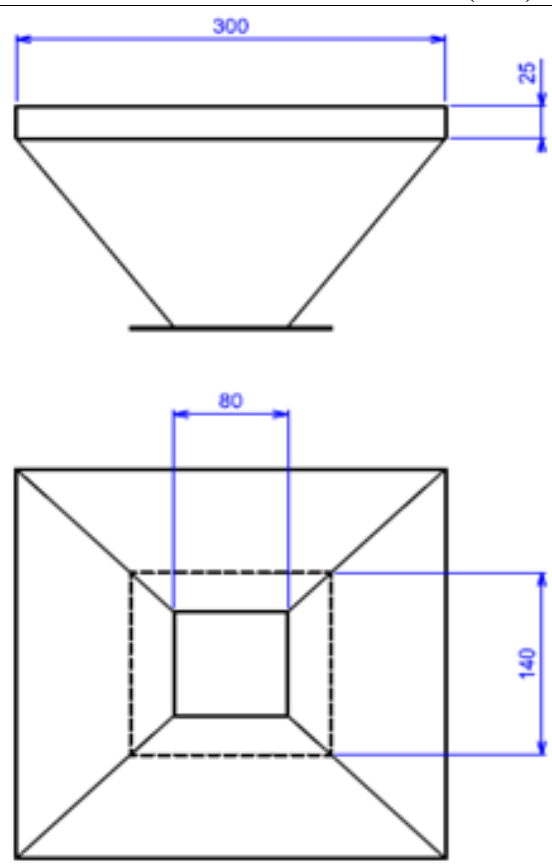
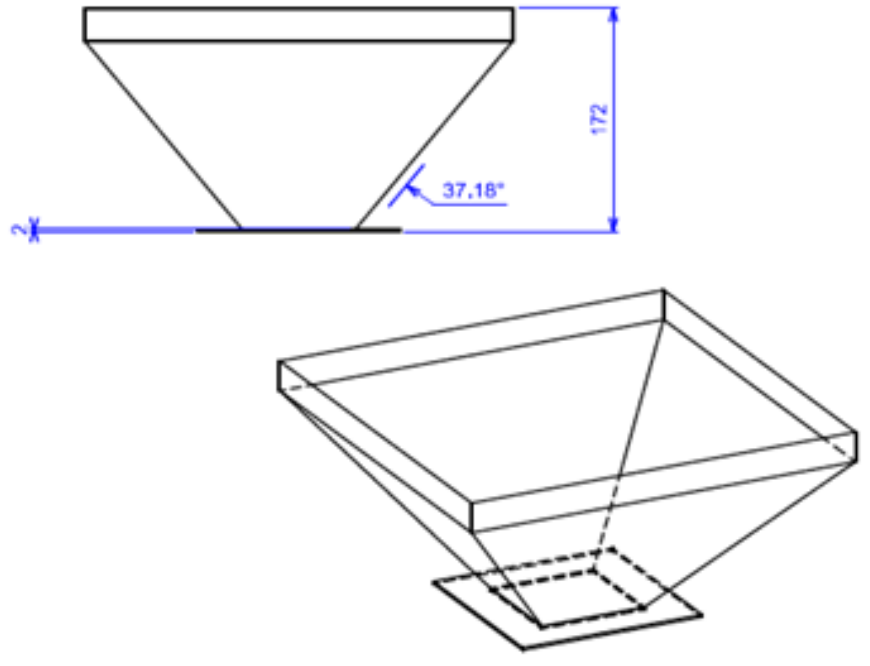

Figure 4:- Machine Hopper Definition Drawing

\section{Design ofFrame:-}

The dimensions of the frame is presented in Figure 5. It was constructed from $45 \times 45 \times 4 \mathrm{~mm}$ mild steel (MS) angle iron. The frame serves as the skeleton for other parts. 


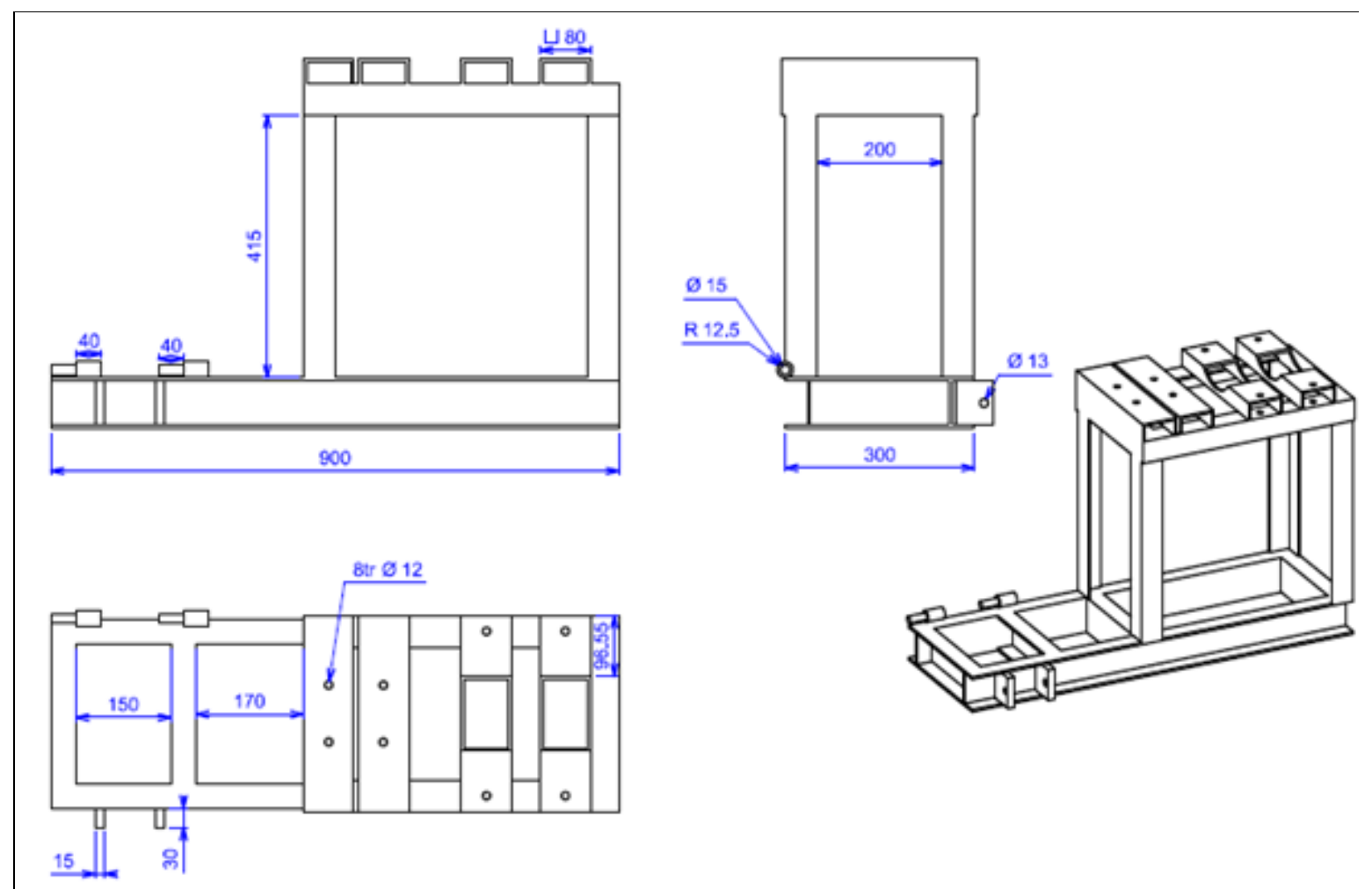

Figure 5:- Frame Definition Drawing.

Operation of the Expelling Machine for Briquettes made from cashew nut shell pyrolysisbiochars:-

The principle of operation involves the rotation of the helically flighted shaft in the cylinder. The electric motor was used to power the machine. The raw material are fed from the hopper to the screw conveyor which rotates in the expeller housing. When the electric motor is switch on, the screw, which conveys raw materials, moves and packs the raw material being heated along the passage to the far side. The compression is achieved by decreasing pitch of the auger, designed to act as a screw press. Thus, the machine compacts and expels the briquettes.

\section{Machine Performance Evaluation:-}

The performance indicators evaluated are the throughput capacity and expelling rate.

\section{Throughput capacity:-}

It quantifies the machine's capability in terms of quantity of cashew nut shells' biochars it can process, per unit time. It can be quantified using(Harmanto et al. 2009) relationship, as stated in following equation.

Throughputcapacity $\left(\frac{\mathrm{kg}}{\mathrm{hr}}\right)=\frac{\text { cashew nut shell pyrolysis biochars }}{\text { Timetakenforexpelling }}(3)$

\section{Expelling rate:-}

The expelling rate quantifiesthe number of expelling Briquettes that machine is capable of expelling per unit time.

Expellingrate $=\frac{\text { Numberof expellingBriquettes }}{\text { Timetakenforexpelling }}$ 


\section{Results and Discussion:-}

The summary ofpreliminary results of performance evaluation of the developed Expelling Machine, for Briquettes made of biochars from pyrolysis of cashew nut shells, is presented in Table 1.

Table 1:- Preliminary results of the performance evaluation of the developed Expelling Machine for Briquettes made of biochars from pyrolysis of cashew nut shells

\begin{tabular}{|l|l|l|}
\hline \multicolumn{2}{|c|}{} & $\begin{array}{l}\text { Expelling Machine for Briquettes made of biochars } \\
\text { from pyrolysis of cashew nut shells }\end{array}$ \\
\hline \multirow{2}{|c|}{$\begin{array}{l}\text { Structural } \\
\text { characteristics } \\
\text { energy }\end{array}$} & Overall dimensions & $0.90 \mathrm{~m} \times 0.31 \mathrm{~m} \times 0.89 \mathrm{~m}$ \\
\cline { 2 - 3 } & Loading height & $0.89 \mathrm{~m}$ above ground \\
\cline { 2 - 3 } $\begin{array}{l}\text { Technical } \\
\text { Performances }\end{array}$ & Energy used & Electric Motor \\
\cline { 2 - 3 } & Throughput(kg/hr) & $500.32 \pm 1.266$ \\
\cline { 2 - 3 } $\begin{array}{l}\text { Final Prodling Rate (number/hr) } \\
\text { Characteristics }\end{array}$ & Efficiency $(\%)$ & $1000 \pm 1.115$ \\
\cline { 2 - 3 } & Weight $(\mathrm{g})$ & $96.500 \pm 0.182$ \\
\cline { 2 - 3 } & Shape & 200 \\
\hline
\end{tabular}

The results presented in Table 1 show that the throughput of machine is $500.32 \mathrm{~kg} / \mathrm{hr}$ and expelling rate, 1000 briquettes/hours. It's a better performance compared to those of manual lever press (Godjo 2017)and hydraulic press which have respectively displayed $10 \mathrm{~kg} / \mathrm{hr}$ and $90 \mathrm{~kg} / \mathrm{hr}$ as throughput and 70briquettes/hours and 420 briquettes/hours as expelling rates. The increase in throughput of the developed machine may be attributed to the reached pressure. In fact, the attained pressure, for kinds of Expelling Machines, is from 610 to $1350 \mathrm{kN} / \mathrm{m}^{2}$ (Orhevba et al. 2016 ; Okoye, Jiang, and Hui 2008 ;Bahadar, Khan, and Mehran 2013) against 180 kN/m² for manual lever press and $350 \mathrm{kN} / \mathrm{m}^{2}$ for hydraulic press.

\section{Conclusion:-}

The Expelling Machine, for Briquettes made of biochars from pyrolysis of cashew nut shells, is designed. This machine is conceived as ideal for biomass briquetting. Its expected capacity is $500 \mathrm{~kg} / \mathrm{hr}$ and it can expel briquettes at the rate of 1,000 briquettes/hr. This results are of interest from the point of view of technic,ergonomic and environmental. Indeed, the capacity and the overall dimensions of the machine are those allowing a better ease and improving the use. Finally, the designed machine contributes to enhance the environmental footprint.

\section{References:-}

1. Bahadar, Ali, M. B. Khan, and Taqi Mehran. 2013. "Design and Development of an Efficient Screw Press Expeller for Oil Expression from Jatropha Curcas Seeds: A Computational Flow Dynamics Study of Expeller for Performance Analysis." Industrial and Engineering Chemistry Research 52(5):2123-29.

2. Chou, Chuen-Shii, Sheau-Horng Lin, and Wen-Chung Lu. 2009. "Preparation and Characterization of Solid Biomass Fuel Made from Rice Straw and Rice Bran.” Fuel Processing Technology 90(7-8):980-87. Retrieved (http://dx.doi.org/10.1016/j.fuproc.2009.04.012).

3. Das, Piyali and Anuradda Ganesh. 2003. "Bio-Oil from Pyrolysis of Cashew Nut Shell - A near Fuel." Biomass and Bioenergy 25(1):113-17.

4. Das, Piyali, T. Sreelatha, and Anuradda Ganesh. 2004. "Bio Oil from Pyrolysis of Cashew Nut ShellCharacterisation and Related Properties." Biomass and Bioenergy 27(3):265-75.

5. Godjo, T. and F. Lanmantchion. 2016. "Design and Performance Evaluation of a Pyrolysis Reactor for Vegetable Biomass Conversion to Usable Energy." International Journal of Current Engineering and Technology 6(5):1865-68.

6. Godjo, T. 2016. "Production et Densification de Biocharbon À Partir Des Coques Déchets D'anacarde Au Bénin.” in Colloque Eau, Déchets et Développement Durable, 7 - 11 mars 2016, Lomé, Togo.

7. Godjo, T. 2017. "Densification and Analysis of the Physical Properties of Bio-Coal Produced from the Pyrolysis Cashew Nut Shells in Benin." International Journal of Innovation and Applied Studies 19(3):614-20.

8. Godjo, T., J. P. Tagutchou, Pascale Naquin, and Rémy Gourdon. 2015. "Valorisation Des Coques D'anacarde Par Pyrolyse Au Benin." Revue Déchets Sciences et Techniques 70.

9. Harmanto, A., E. Hendriadi, M. Rahmarestia, and J. Wiyono. 2009. "Performance Test of a Screw-Press 
Machine for Extracting Jatropha Curcasseed into Crude Oil as an Alternative Energy Source." Indonesian Journal of Agriculture 2(1):35-40.

10. Hassan, S., L. S. Kee, and Hussain H. Al-Kayiem. 2013. "Experimental Study of Palm Oil Mill Effluent and Oil Palm Frond Waste Mixture as an Alternative Biomass Fuel." Journal of Engineering Science and Technology $8(6): 703-12$.

11. Höök, Mikael and Xu Tang. 2013. "Depletion of Fossil Fuels and Anthropogenic Climate Change-A Review." Energy Policy 52:797-809.

12. Lemm, Steven, Benjamin Blankertz, Thorsten Dickhaus, and Klaus-Robert Müller. 2011. "Introduction to Machine Learning for Brain Imaging." NeuroImage 56(2):387-99.

13. Mensah, E. R., K. Karantininis, A. Adegbidi, and J. J. Okello. 2012. "Determinants of Commitment to Agricultural Cooperatives: Cashew Nuts Farmers in Benin." The International Association of Agricultural Economist (IAAE) Triennial Conference.

14. Okoye, Celestine N., Jihai Jiang, and Liu Yu Hui. 2008. "Design and Development of Secondary Controlled Industrial Palm Kernel Nut Vegetable Oil Expeller Plant for Energy Saving and Recuperation." Journal of Food Engineering 87(4):578-90.

15. Orhevba, B. A., O. Chukwu, Z. D. Osunde, and V. Ogwuagwu. 2016. "Studies on the Effect of Pressure on Yield of Mechanically Expressed Neem Seed Kernel Oil." Global Journal of Engineering, Design \& Technology 2(5):20-24.

16. Rattanongphisat, W. and S. Chindaruksa. 2011. "A Bio-Fuel Briquette from Durian Peel and Rice Straw: Properties and Economic Feasibility." NU Science Journal 8(2):1-11. Retrieved (http://www.sci.nu.ac.th/sciencejournal/index.php/journal/article/view/221).

17. Tagutchou, J. P. and P. Naquin. 2012. "Caractérisation et Traitement Thermochimique Des Coques D'anacarde En Vue de Leur Valorisation Énergétique Dans Les Procédés de Transformation Artisanale de Noix de Cajou." Revue Déchets Sciences et Techniques 62:28-35.

18. Tippayawong, N., C. Chaichana, A. Promwangkwa, and P. Rerkkriangkrai. 2011. "Gasification of Cashew Nut Shells for Thermal Application in Local Food Processing Factory." Energy for Sustainable Development 15(1):69-72.

19. Wood, Allen J. and Bruce F. Wollenberg. 1996. Power Generation, Operation, and Control. Retrieved (http://electrical.csu.edu.tw/Material/99/N4T/EE4Y/95856.pdf). 